\title{
Halu Oleo University Indonesia towards the green campus through the application of solar energy to support the electricity generation
}

\author{
Mustarum Musaruddin ${ }^{\mathrm{a}}$, Usman Rianse ${ }^{\mathrm{b}}$, Aditya Rachman ${ }^{\mathrm{c}}$ \\ ${ }^{a}$ Electrical Engineering Department of Halu Oleo University Kendari 93232 Indonesia \\ ${ }^{b}$ Agricultural Department of Halu Oleo University Kendari 93232 Indonesia \\ ${ }^{c}$ Mechanical Engineering Department of Halu Oleo University Kendari 93232 Indonesia
}

\begin{abstract}
The role of university to raise the awareness on the importance of the clean renewable energy development for communities is so indispensible. The application of the solar energy technology in the university area to support the electricity generation could be an appropriate starting point to deliver the awareness to students, the representation of the community in the campus. Halu Oleo University, one of the universities in Southeast Sulawesi, a developing province in eastern part of Indonesia with still current lack of the energy access, has potential to contribute in generating the student's awareness by applying of the solar technology in the campus area. One of the important initial stages to apply this technology in the campus is to obtain the information on the solar energy potential and the appropriate strategies for the technology to obtain high sun power output. This information should be very useful in determining whether the technology will be technically and economically feasible. The aim of this study is to assess the potential solar energy, the technical strategy and the economic on the application of the photovoltaic (PV) energy technology in the campus area of Halu Oleo University Indonesia. The mathematical model of the solar radiation falling on a tilted surface, combined with the data of the solar global radiation obtained from the NASA Langley Research Center Atmospheric Science Data Center Surface meteorological and Solar Energy (SSE) web portal and the economical model of the Levelized Cost of Energy (LCOE) are utilized to perform the assessment. It proposes some technical strategies on various tilt angle and orientation on a solar PV panel. The result shows that the potential annual solar energy is around $2092 \mathrm{KWH} / \mathrm{m}^{2}$ annually. In the technical strategy aspect, positioning the panel parallel to the earth surface can derive the high annual energy generation (around $209 \mathrm{KWH} / \mathrm{m}^{2}$ ) and potentially obtain the lower energy cost than those of the government solar energy purchased price (Feed-in Tariff) and some other energy costs.
\end{abstract}

Keywords: Halu Oleo University, solar, energy, potential, strategy, economic

\section{Introduction}

Energy is one of the importance elements for the development. It is probably acceptable that many nations would possibly pose many massive challenges when the energy is not present. Many sectors, such as industry, mining, transportation, communication, even agriculture depend largely on the existence of the energy. In present days, the majority of energy source comes from unclean limit fossil fuels. Many believe that the utilization of these energies poses many constraints, including the limitation, the unbalanced of the supply and demand, the unpredictable price and the detrimental environmental consequence. The application of the clean decentralized renewable energy can bring optimism in reducing the dependence on these unclean limit energy sources.

For Indonesia, a developing nation, the application of the clean decentralized renewable energy should be prioritized. This is driven by the fact that, Indonesia is one of the developing nations, which seems still to pose the problems on the inequality electricity distribution and the low energy per-capita for its

\footnotetext{
* Manuscript received June 4, 2015; revised August 2, 2015.

Corresponding author. Aditya Rachman Tel.: +6285810780290; E-mail address: aditya_rchmn@yahoo.com.

doi: $10.12720 /$ sgce.4.2.151-158
} 
communities, especially in eastern part [1]. Indeed, the condition of geography; many islands, and topography; mountainous and hilly land characteristics of this nation has become the bottleneck for the power distribution. The high pace on the energy demand unbalanced with the domestic energy supply can also be another potential challenge posed by Indonesia in present day [2]. Furthermore, the detrimental consequences on the global climate change over the majority utilization on the fossil energies can be also another constraint [2].

Solar energy can be one of the locally available clean renewable sources potentially supporting the power supply for the communities in this nation. This can be driven by the fact that most of its regions geographically are located around the equator line which benefits in obtaining relatively high solar radiation annually. Indonesia, theoretically, has a great potential for developing the solar power system as its average daily solar radiation is above $4 \mathrm{KWH} / \mathrm{m}^{2} /$ day annually [3]. To stimulate the solar energy development, the government of Indonesia, under the regulatory of Minister of Energy and Mineral Resources 17/2013, one of the umbrella regulatory frameworks for the development of the solar energy technology, obligates the state electricity company to purchase the electricity generated by the solar photovoltaic power plant based on the capacity quota offered through online public auction by the Directorate General of New Renewable Energy and Energy Conservation. The maximum purchased price (Feed-in-Tariff) is $0.25 \mathrm{USD} / \mathrm{KWH}$ or $0.30 \mathrm{USD} / \mathrm{KWH}$ if local components in a solar photovoltaic power plant amount to at least 40 percent.

Southeast Sulawesi, one of the developing regions in the eastern part of Indonesia, inhabited by around two million people, has also potential for the development of the renewable power based on the solar energy. The position close to the equator line should benefit this province in obtaining the abundant solar radiation [4]. Unfortunately, the availability of the energy still also becomes a challenge for the development in this region.

The effort of raising the public awareness on the potential solar energy to cope with present energy challenge is so indispensable. Halo Oleo University, one of the universities in Southeast Sulawesi, has potential role to raise the awareness on the importance of clean decentralized renewable energy sources, especially solar power, for communities in this province. This is because the university has responsibilities to transfer knowledge, skill and attitude toward students, a representation of communities, to conduct research and to involve in the community development. The program on the application of the solar energy to support the local electricity generation in the campus should be an appropriate initial stage to stimulate the knowledge, skill and attitude to students in order to raise their awareness on the need of the clean energy technology development. Indeed, the existence of this technology in the campus should stimulate the research activities on the renewable energy development in which the results hopefully can be implemented to communities.

In applying the solar technology in the campus, many aspects are required to be considered. The energy potential and the decision on the appropriate strategies on the technology in obtaining the high energy performance are among the aspects. This information should be very useful in determining whether the technology will be technically and economically feasible or not to be put into application. The aim of this study is to assess the potential solar energy and the technical strategies on the application of the photovoltaic (PV) energy technology in the campus area of Halu Oleo University. An economic assessment on the proposed energy technology is also performed in this study.

\section{Literature Study}

\subsection{Southeast sulawesi}

Southeast Sulawesi is one of the developing regions in eastern part of Indonesia, with the percentage of people living in poor condition around 13 percent, in which most of them live in rural regions, the Gross Domestic Product (GDP) per-capita around 1600 dollars (Indonesia : 3000 dollars per-capita) and the Human Development Index (HDI) around 71 (Indonesia: 73) [5]. The total electricity consumption in this province is only around $520 \mathrm{GWH}$ annually, equal to the electricity per-capita of around $227 \mathrm{KWH}$ 
annually, considerably less than that of Indonesia (712 KWH annually) [1]. Instead of the low electricity per-capita, the electricity ratio in this province is only 52 percent. On this percentage, the number of households with the electricity connection is only around 270 thousands of the total 520 thousand households [5].

\subsection{Halu Oleo University (UHO)}

Halu Oleo University (UHO) was established in 1964 as a private college of the University of Hasanuddin Makassar filial. After seventeen years, the university was inaugurated as the first public university in Southeast Sulawesi by the Director General of Higher Education and as the $42^{\text {th }}$ public universities in Indonesia. The university comprises of two main areas; the campus of Kemaraya occupying 7 hectares, and the main campus of Andounohu occupying 260 hectares (see Fig. 1(a)). Currently, the university has 11 faculties [6].

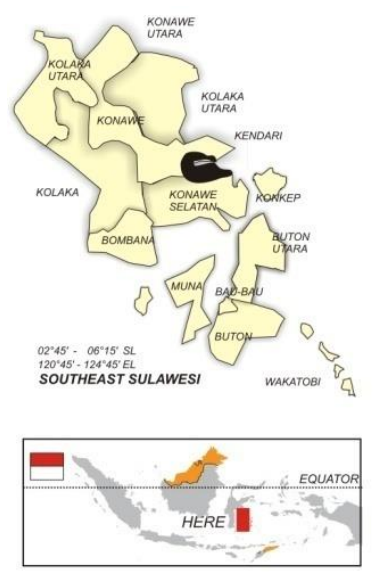

(a)

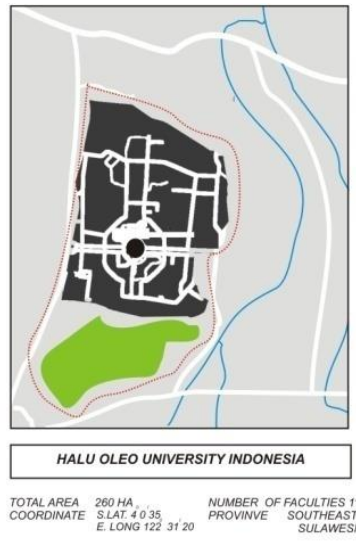

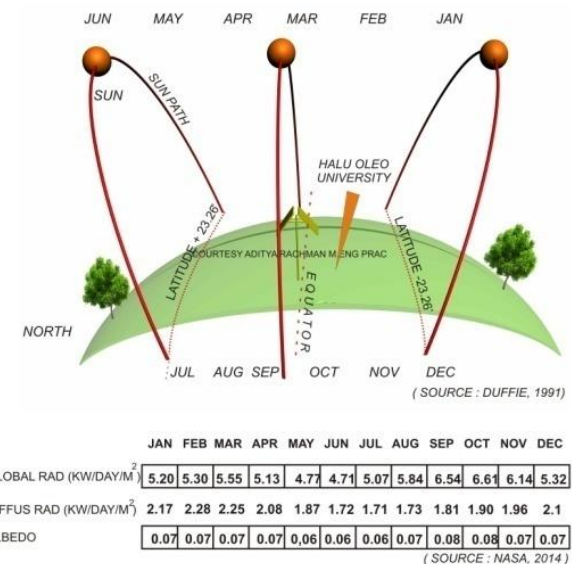

(b)

Fig. 1. (a) Map: Southeast Sulawesi and Halu Oleo University (main campus) (b) The monthly relative solar position to the latitude angle and the global solar radiation in Halu Oleo University [7], [8].

The location of UHO main campus should be potential for building the power plant based on the solar energy as geographically, it is at $4^{\circ} 0^{\prime} 35$ South Latitude and 122 $31^{\prime} 20$ East Longitude, which is close to the equator line. The solar position by month [7] and the data of the solar radiation on the main campus of UHO can be seen in Fig. 1(b).

\subsection{Mathematical model for determining solar energy potential}

In order to predict the solar energy potential and the solar technology performance, many methods are available. Applying the experiment on the solar technology using sun panel and pyranometer, and the simulation using computer program are among the methods. Another method alternatively applied to predict the solar energy potential and the solar technology performance is a mathematical model of solar radiation in [9]. This mathematical model is based on the total daily solar radiation received by a tilted surface. In this model, the average monthly daily total solar radiation $\left(\mathrm{H}_{\mathrm{T}}\right)\left(\mathrm{KWH} / \mathrm{m}^{2}\right.$-day $)$ on the surface is assumed to consist of the direct beam $\left(\mathrm{H}_{\mathrm{B}}\right)$, diffuse $\left(\mathrm{H}_{\mathrm{D}}\right)$ and reflected $\left(\mathrm{H}_{\mathrm{R}}\right)$ components of the radiation on the surface, formulated by

$$
H_{T}=H_{B}+H_{D}+H_{R}
$$

where, $H_{B}$ is the daily beam radiation received on an inclined surface $\left(\mathrm{KWH} / \mathrm{m}^{2}\right.$-day) which can be expressed as 


$$
H_{B}=\left(H_{g}-H_{d}\right) \frac{\operatorname{Cos}(\theta)}{\operatorname{Cos}\left(\theta_{z}\right)}
$$

where, $\mathrm{H}_{\mathrm{g}}$ and $\mathrm{H}_{\mathrm{d}}$ are the monthly mean daily global and diffuse radiations on a horizontal surface respectively $\left(\mathrm{KWH} / \mathrm{m}^{2}\right.$-day), $\theta_{\mathrm{z}}$ is the zenith angle $\left(^{\circ}\right)$ and $\theta$ is the incidence angle $\left(^{\circ}\right)$, which can be obtained from following equation [7] ( see Fig. 2)

$$
\begin{aligned}
\operatorname{Cos}(\theta)=\operatorname{Sin}(\delta) & \operatorname{Sin}(\Phi) \operatorname{Cos}(\beta)-\operatorname{Sin}(\delta) \operatorname{Cos}(\Phi) \operatorname{Sin}(\beta) \operatorname{Cos}(\gamma) \\
& +\operatorname{Cos}(\delta) \operatorname{Cos}(\Phi) \operatorname{Cos}(\beta) \operatorname{Cos}(\omega)+\operatorname{Cos}(\delta) \operatorname{Sin}(\Phi) \operatorname{Sin}(\beta) \operatorname{Cos}(\gamma) \operatorname{Cos}(\omega) \\
& +\operatorname{Cos}(\delta) \operatorname{Sin}(\beta) \operatorname{Sin}(\gamma) \operatorname{Sin}(\omega)
\end{aligned}
$$

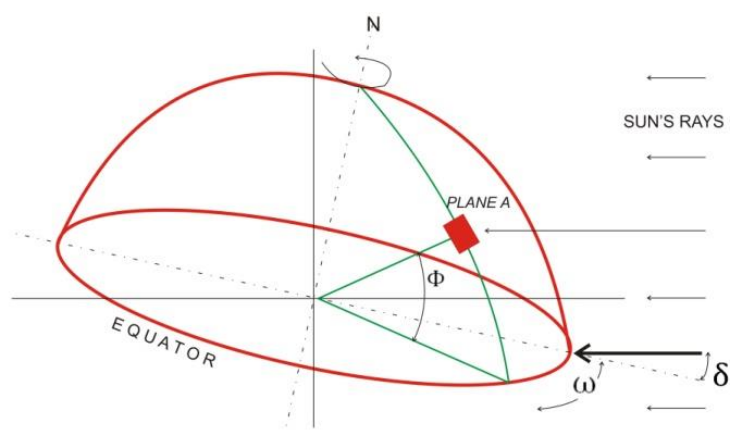

SOURCE : SOLAR ENGINEERING OF THERMAL PROCESSES, SECOND EDITION, J. A. DUFFIE, W. A. BECKMAN, WILEY,
1991.

(a)

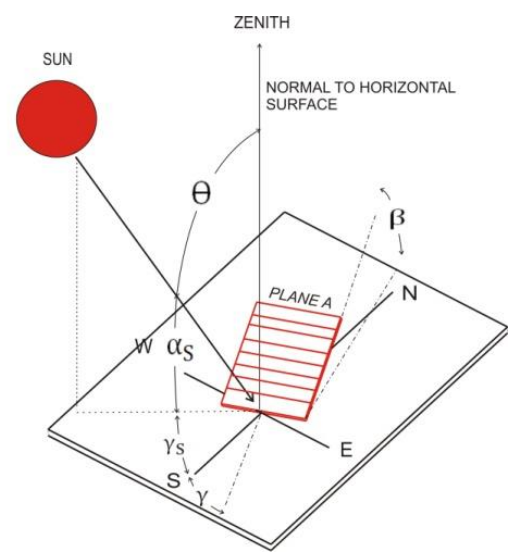

(b)

Fig. 2. (a) Sun rays on a plane (b) the detail [7].

where, $\omega$ is the hour angle $\left(^{\circ}\right), \varphi$ is the latitude angle $\left(^{\circ}\right), \beta$ is the tilt angle of the panel surface $\left(^{\circ}\right), \gamma$ is the surface azimuth angle $\left({ }^{\circ}\right)$ and $\delta$ is the declination of the angular position of the sun at solar noon with respect to the plane of the equator $\left({ }^{\circ}\right)$ (see Fig. 2).

$\mathrm{H}_{\mathrm{D}}$ is the diffuse solar radiation ( $\mathrm{KWH} / \mathrm{m}^{2}$-day), formulated by

$$
H_{D}=\left(H_{g} \rho\right) \frac{(1-\operatorname{Cos}(\beta))}{2}
$$

where, $\rho$ is the ground albedo.

$\mathrm{H}_{\mathrm{R}}$ is the reflected solar radiation $\left(\mathrm{KWH} / \mathrm{m}^{2}\right.$-day), formulated by

$$
H_{R}=H_{d} R_{d}
$$

where $R_{d}$ is the ratio of the average daily diffuse radiation on a tilted surface, to that on a horizontal surface.

\subsection{Mathematical model for the economic assessment}

Many models are available to assess the economic feasibility of the energy generation projects. The levelized Cost of Energy (LCOE) model is one of the analytical tools that can be used to consider the grid parity for emerging technologies such as solar technology [10]. The calculation for the LCOE is the Net Present Value (NPV) of the total life cycle costs of the project divided by the quantity of the energy generated over the system life, formulated by

$$
L C O E=\frac{\sum_{t=1}^{y} \frac{I_{t}+M_{t}+F_{t}}{(1+r)^{t}}}{\sum_{t=1}^{y} \frac{E_{t}(1-d)}{(1+r)^{t}}}
$$


where, $I_{t}$ is the investment expenditures in the year $t$ (USD), $M_{t}$ is the operation and maintenance expenditures (O\&M) in the year $t$ (USD), $F_{t}$ is the fuel expenditures in the year $t$ (USD), $E_{t}$ is the electricity generation in the year $\mathrm{t}(\mathrm{KWH}), \mathrm{r}$ is the discount rate, $\mathrm{d}$ is the annual energy degradation (percent-annually) and $\mathrm{y}$ is the life of the project (year).

\subsection{Solar energy technology performance}

In applying the solar technology, the performance is one of the paramount aspects. The high performance is so desirable, thus the solar energy machine will effortlessly deliver the economic attractiveness on its application. Instead of selecting the advanced sun collector material, matching the position of the collector to the sun position plays an essential role in obtaining the high performance. It is necessary that the position of collector is adjusted in such way that it enables the surface to receive as much as the perpendicular element of the solar radiation to obtain the maximum energy output. As the position of the sun is believed not only to change in second and hour, but also in day and month, the amount of the perpendicular solar radiation can be varying, yielding in the change on the performance. This makes the effort to gain as much as solar energy on the panel in order to obtain the desirable performance is not so simple.

Adjusting the inclination and the orientation of solar panel is one of the simply methods to obtain as much as the perpendicular element of the solar radiation. Many studies have included the aspects of the optimization of the tilt angle and the orientation in their work in order to maximize the solar technology power output. A study in [11] investigates the optimum orientation and tilt angle of a PV panel in Cairo Egypt using a computer subprogram verified at different meteorological conditions. It is found that PV module with south direction at the tilt angle ranging from $20^{\circ}$ to $30^{\circ}$ generates the maximum annual energy. A study in [12] using a particle-swarm optimization method with nonlinear time-varying evolution (PSO-NTVE) shows that the optimum tilt angle of PV modules in some locations in Taiwan ranges from $15^{\circ}$ to $19^{\circ}$ in the south orientation. A study in [13] optimizes the tilt angle and direction for a PV panel in Ontario Canada to obtain the maximum revenue on the application of the solar power technology. It is found that the optimum tilt angle is at the angles slightly less than the latitude coordinates at the south orientation. A study in [14] simulates the performance of a Photovoltaic (PV) installation with inclusion of the tilt and orientation optimization using SolarGIS-PV Planner for household installation in Surabaya Indonesia. It is found that the optimum panel orientation is at Northwest with the inclination of $13^{\circ}$.

\section{Methodology}

This study uses mathematical model of the solar radiation falling on a tilted surface to assess the solar energy potential and the solar technology performance. The calculation of the potential solar energy is based on the amount of the average monthly daily total solar radiation on a horizontal surface. It proposed technical PV strategies, including the optimum angle and direction for the solar collector. In this study, the data of the daily global radiation, the daily diffuse solar radiation and the ground albedo is obtained from the NASA Langley Research Center Atmospheric Science Data Center Surface meteorological and Solar Energy (SSE) web portal supported by the NASA LaRC POWER Project using data of 22-year monthly \&annual average (July 1983 - June 2005) [8]. The data from a location in the rector building in the Halu Oleo Andounohu campus (based on the latitude and longitude coordinates (40'35 South Latitude and $122^{\circ} 31^{\prime} 20$ East Longitude)) is utilized as the base reference for the calculation.

The economic assessment is conducted by employing the model of the Levelized Cost of Energy (LCOE). The scenario of proposing a solar power plant with the overall capacity of $2 \mathrm{MW}$ is included. This plant has power efficiency 0.1 with the annual sunshine day percentage variation of 40 percent and 60 percent and the annual energy degradation of 0.01 . The investment cost is $4.2 \mathrm{USD} / \mathrm{KW}$ and the operating and maintenance cost is $27.7 \mathrm{USD} / \mathrm{KW}$ annually [15]. The discount rate is varied by 2 percent and 7 percent with the life of the project of 25 years. 


\section{Results}

\subsection{Energy}

Fig. 3(a) shows the potential solar energy in the campus area of Halu Oleo University. The total potential solar energy is around $2092 \mathrm{KWH}$ per-meter square annually. The pattern of the potential solar energy is varying by month. At the beginning of the year, the solar energy potential is around 180 $\mathrm{KWH} / \mathrm{m}^{2}$. Then, it increases to more than $190 \mathrm{KWH} / \mathrm{m}^{2}$ in March, before decreasing to around 140 $\mathrm{KWH} / \mathrm{m}^{2}$ in June. Then, it increases again in October to almost $200 \mathrm{KWH} / \mathrm{m}^{2}$, before decreasing to around $176 \mathrm{KWH} / \mathrm{m}^{2}$ at the end of the year. This phenomenon can be related by the condition of the annual pattern on the global solar radiation in Southeast Sulawesi. As seen in the Figure 1(b), there is a tendency that in March and October the solar radiation is so high, while at the mid of the year, the solar radiation is so low.

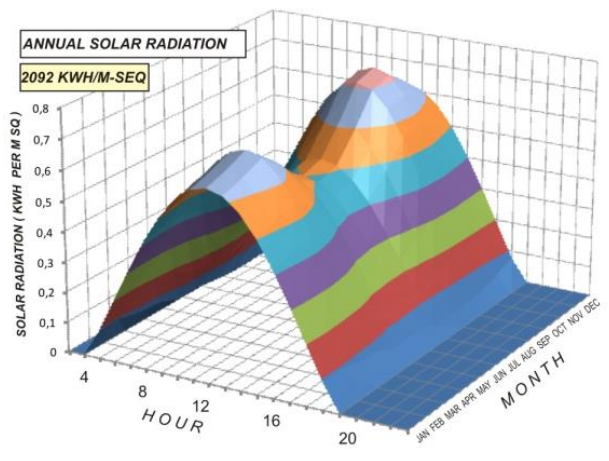

(a)

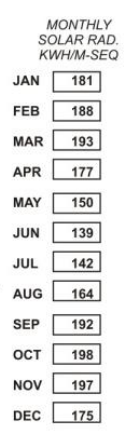

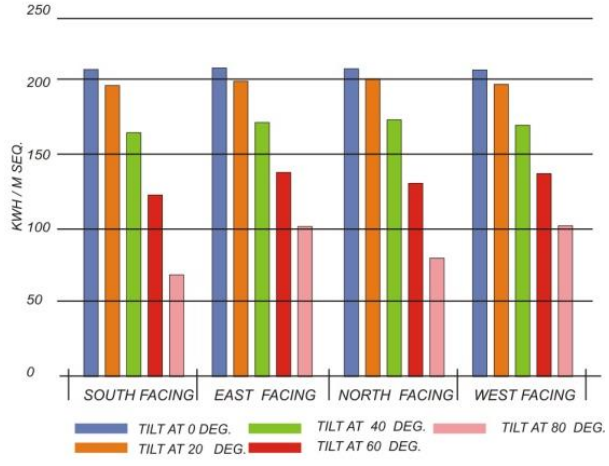

(b)

Fig. 3. (a) The potential energy (b) The annual solar energy.

Fig. 3(b) shows the annual energy output of the PV technology in different tilt angles and orientations. It is shown that in all panel directions, there is a tendency that at the zero tilt angle they obtain high annual energy generated, around $209 \mathrm{KWH} / \mathrm{m}^{2}$ annually. As the angle is increased to $20^{\circ}$, the annual energy generated decreases moderately, while as the angle is increased further, the energy decreases sharply. For the south facing panel, adjusting the tilt angle to $40^{\circ}, 60^{\circ}$ and $80^{\circ}$ can decrease the annual energy to $153 \mathrm{KWH} / \mathrm{m}^{2}, 112 \mathrm{KWH} / \mathrm{m}^{2}$ and $64 \mathrm{KWH} / \mathrm{m}^{2}$ respectively, relative to that of the zero inclined angle. For the east facing panel, increasing the tilt angle to $40^{\circ}, 60^{\circ}$ and $80^{\circ}$ can reduce the annual energy to $158 \mathrm{KWH} / \mathrm{m}^{2}, 127 \mathrm{KWH} / \mathrm{m}^{2}$ and $93 \mathrm{KWH} / \mathrm{m}^{2}$ respectively, relative to that of the zero inclined angle. Increasing the panel angle to $40^{\circ}, 60^{\circ}$ and $80^{\circ}$ in the north orientation can reduce the annual energy to 161 $\mathrm{KWH} / \mathrm{m}^{2}, 122 \mathrm{KWH} / \mathrm{m}^{2}$ and $74 \mathrm{KWH} / \mathrm{m}^{2}$ respectively, relative to that of the zero inclined angle. In west facing panel, setting the tilt angle to $40^{\circ}, 60^{\circ}$ and $80^{\circ}$ can reduce the annual energy to $158 \mathrm{KWH} / \mathrm{m}^{2}, 127$ $\mathrm{KWH} / \mathrm{m}^{2}$ and $93 \mathrm{KWH} / \mathrm{m}^{2}$ respectively, relative to that of the zero inclined angle.

Based on these results, adjusting the position of solar panel almost parallel to the earth surface is highly recommended for the installation in order to derive the high annual energy generated. Too much tilt angle adjustment into the panel can reduce annual energy generation.

\subsection{Economic}

Fig. 4 shows the LCOE from the proposed scenario and its comparison to the solar energy purchased price under the government regulatory (Feed-in-Tariff) and to other energy costs. At 7 percent discount rate, the $\mathrm{LCOE}$ is more than $0.3 \mathrm{USD} / \mathrm{KWH}$ at 40 percent sunshine days. As the discount rate decreases to 2 percent with the increase in the sunshine day, the energy cost decreases sharply. At the scenario of 60 
percent sunshine days and 2 percent discount rate, it is possible to obtain the LCOE lower than 0.15 USD/ KWH.

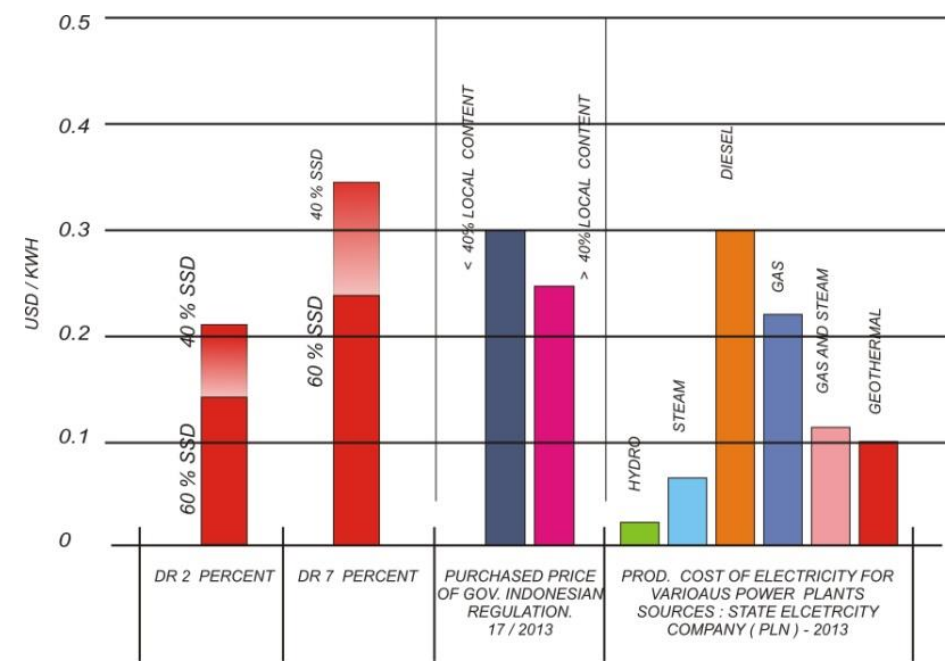

Fig. 4. The Levelized Cost of Energy (LCOE) of the proposed economic scenarios.

In comparison to the solar purchased price (Feed-in-Tariff), it is shown that, in almost all proposed scenario, it is possible to obtain the lower energy costs, except for that with 7 percent discount rate and 40 percent sunshine day. In comparison to other energy costs, it seems that the solar energy cost is difficult to compete well to those of hydro, steam (coal), gas-steam and geothermal, but not with those of diesel and gas.

\section{Conclusion}

This study has assessed the potential solar energy, the technical strategy and the economic on the application of the photovoltaic (PV) energy technology in the campus area of Halu Oleo University. Following is the conclusion that can be drawn.

The potential annual solar energy is around $2 \mathrm{MWH} / \mathrm{m}^{2} /$ year. The optimum panel position is at horizontal direction (parallel with earth surface), generating about ten percent of the energy potential available annually under the same exposed area. Almost in all proposed economic scenario, it can obtain lower energy costs than those of the solar purchased price (Feed-in-Tariff). In comparison to the other energy costs, it seems that the solar energy cost can compete well to those of the diesel and gas, but not with those of hydro, steam (coal), gas-steam and geothermal.

\section{References}

[1] State Electricity State Company (PLN Persero Indonesia). (2013). Statistic of National Electricity State Company. [Online] www.pln.co.id/dataweb/STAT/STAT2012IND.pdf

[2] EIA (U.S. Energy Information Administration). (2013). Indonesia Overview [Online]. Available: http://www.eia.gov/countries/cab.cfm?fips=id

[3] Fathoni AM, Agya NU, Kristianto MA. A technical and economic potential of solar energy application with feed-in tariff policy in Indonesia. Procedia Environmental Sciences, 2014;20:89-96.

[4] Balaka R, Rachman A, Jaya LDM. Mitigating climate change through the development of clean renewable energy in Southeast Sulawesi, a developing region in Indonesia. International Journal of Energy, Information and Communications, 2013;4(4):3342.

[5] Statistical Centre Bureau of Indonesia (BPS Indonesia). (2013). The number of poor people, the line of poverty, the index of poverty and severe poverty index based on provinces 2013. [Online]. Available: http://www.bps.go.id/tab_sub/view.php?kat=1\&tabel=1\&daftar=1\&id_subyek=23\&notab=1 
[6] Halu Oleo Unievrsity, Brief History. (2015). [Online]. Available: http://uho.ac.id/profil.php?read=6

[7] Duffie JA, Beckman WA. Solar Engineering of Thermal Processes. Second Edition, Wiley; 1991.

[8] NASA, Surface Meteorology and Solar Energy : A Renewable Energy Resource Web Site, NASA Langley Research Center Atmospheric Science Data Center Surface Meteorological and Solar Energy (SSE) Web Portal Supported by the NASA LaRC POWER Project, 2014.

[9] Benghanem M. Optimization of tilt angle for solar panel: Case study for Madinah, Saudi Arabia. Applied Energy, 2011;88(4): 1427-1433.

[10] Branker K, Pathak MJM, Pearce JM. A review of solar photovoltaic levelized cost of electricity. Renewable \& Sustainable Energy Reviews, 2011;15:4470-4482.

[11] Hussein HMS, Ahmad GE, El-Ghetany HH. Performance assessment of photovoltaic modules at different tilt angles and orientations. Energy Conversion and Management, 2004;45(15-16):2441-2452.

[12] Chang YP. Optimal the tilt angles for photovoltaic modules in Taiwan. International Journal of Electrical Power and Energy Systems, 2010;32(9):956-964.

[13] Rowlands IH, Kemery BP, Morrison IB. Optimal Solar-PV tilt angle and azimuth: An Ontario (Canada) case-study. Energy Policy, 2011;39(3):1397-1409.

[14] Tarigana E, Purba LD. Assessment of PV Power generation for household in surabaya using solar GIS-pvPlanner simulation. Energy Procedia, 2014;47:85-93.

[15] U.S. Energy Information Administration, Updated Capital Cost Estimates for Utility Scale Electricity Generating Plants, US Department of Energy, 2013. 